\title{
Prospects for Alkaline Anion-Exchange Membranes in Low Temperature Fuel Cells
}

John R. Varcoe* and Robert C. T. Slade

Chemistry, The University of Surrey, Guildford, Surrey GU2 7XH, United Kingdom.

Tel: $+44(1483) 682616 \quad$ Fax: $+44(1483) 686851$

\begin{abstract}
This article introduces the radical approach of applying alkaline anion-exchange membranes (AAEMs) to meet the current challenges with regards to direct methanol fuel cells (DMFCs). A review of the literature is presented with regards to the testing of fuel cells with alkaline membranes (fuelled with hydrogen or methanol) and also to candidate alkaline anionexchange membranes for such an application. A brief review of the directly related patent literature is also included. Current and future research challenges are identified along with potential strategies to overcome them. Finally, the advantages and challenges with the direct electrochemical oxidation of alternative fuels are discussed, along with how the application of alkaline membranes in such fuel cells may assist in improving performance and fuel efficiency.
\end{abstract}

\section{Keywords}

Low temperature, Alkaline anion-exchange membrane, Direct methanol fuel cell, Polymer electrolyte fuel cell.

\footnotetext{
* Author for correspondence (j.varcoe@ @urrey.ac.uk)
} 


\section{Research Challenges for Direct Methanol Fuel Cells (DMFCs)}

The hydrogen-fuelled proton-exchange membrane (PEM) fuel cell (PEMFC) is highly developed, with good performances and power densities obtainable with low catalyst loadings $\left(<0.2 \mathrm{mg} \mathrm{Pt} / \mathrm{cm}^{2}\right.$ electrode area, with the platinum particles usually supported on a carbon substrate) [1,2]. For example, Qi and Kaufmann achieved a high fuel cell power density of $720 \mathrm{~mW} \mathrm{~cm}^{-2}$ (current density of over $1.4 \mathrm{~A} \mathrm{~cm}^{-1}$ at a cell voltage of $\sim 0.5 \mathrm{~V}$ ) at $75^{\circ} \mathrm{C}$ with Nafion ${ }^{\circledR}-112$ membrane, and catalyst loadings of $0.12 \mathrm{mg} \mathrm{cm}^{-2}$ (20\%wt Pt/C) [3]. A further example with a reduced anode catalyst loading was recently reported in the literature by Gamburzev and Appleby [4]; current densities of $600 \mathrm{~mA} \mathrm{~cm}{ }^{-2}$ were obtained at a cell potential of $0.7 \mathrm{~V}\left(420 \mathrm{~mW} \mathrm{~cm}^{-2}\right)$ with Nafion ${ }^{\circledR}-111$ membrane (DuPont, Scheme 1), a cathode platinum loading of $0.2 \mathrm{mg} \mathrm{cm}^{-2}$ and an ultra-low anode platinum loading of $0.05 \mathrm{mg}$ $\mathrm{cm}^{-2}$. Ultra-low catalyst loadings of $0.014 \mathrm{mg} \mathrm{cm}^{-2}$ have also been reported using a novel sputtering method [5,6]. A recent comprehensive review of PEMFC electrodes published by Lister and McLean is recommended for further details on catalyst structures / preparation [7]. However, PEMFCs have a low CO tolerance and so performances are more limited when the hydrogen is supplied from the reformation of organic fuels [8].

The fuel cell reactions for a PEMFC are described below (Figure 1a):

Anode $: \mathbf{H}_{\mathbf{2}} \rightarrow \mathbf{2 \mathbf { H } ^ { + }}+\mathbf{2 \mathbf { e } ^ { - }}\left(E_{a}=0 \mathrm{~V}\right.$ vs. SHE at 1 bar, $\left.298.15 \mathrm{~K}\right)$

Cathode: ${ }^{1} / \mathbf{O}_{2}+\mathbf{2} \mathbf{e}^{-}+\mathbf{2} \mathbf{H}^{+} \rightarrow \mathbf{H}_{2} \mathbf{O}\left(E_{c}=1.23 \mathrm{~V}\right.$ vs. SHE at 1 bar, $\left.298.15 \mathrm{~K}\right)$

Overall: $\mathbf{H}_{2}+{ }^{1} / \mathbf{O}_{2} \mathbf{O}_{\mathbf{2}} \rightarrow \mathbf{H}_{\mathbf{2}} \mathbf{O}\left(E_{\text {cell }}=1.23 \mathrm{~V}\right.$ at 1 bar, $\left.298.15 \mathrm{~K}\right)$

Interest in solid polymer membrane direct methanol fuel cells (DMFCs) stems mainly from the higher volumetric energy density and reversible efficiencies of methanol $\left(\mathrm{CH}_{3} \mathrm{OH}\right.$, often 
denoted $\mathrm{MeOH}$ ) compared with liquid hydrogen (see Table $1[9,10]$ ), and the relative ease of conversion of the current petroleum distribution networks to methanol compared with the costly whole new distribution structure required for hydrogen. The relative advantages, and comparisons of the costs (both fiscal and environmental) of DMFCs compared with PEMFCs (fuelled directly with hydrogen or indirectly fuelled via on-board reformation) are currently a hot source of debate in the transportation sector and have been comprehensively and recently reviewed [11-13].

The fuel cell reactions for a DMFC with proton-transport through an acid membrane are shown below (Figure 1a):

Anode: $\mathbf{C H}_{3} \mathbf{O H}+\mathbf{H}_{2} \mathbf{O} \rightarrow \mathbf{6} \mathbf{H}^{+}+\mathbf{6} \mathbf{e}^{-}+\mathbf{C O}_{2}\left(E_{a}=-0.02 \mathrm{~V}\right.$ vs. SHE at 1 bar, $\left.298.15 \mathrm{~K}\right)$

Cathode: ${ }^{\mathbf{3}} / \mathbf{2}_{\mathbf{2}} \mathbf{O}_{\mathbf{2}}+\mathbf{6} \mathbf{e}^{-}+\mathbf{6} \mathbf{H}^{+} \rightarrow \mathbf{3} \mathbf{H}_{2} \mathbf{O}\left(E_{c}=1.23 \mathrm{~V} v\right.$ s. SHE at 1 bar, $\left.298.15 \mathrm{~K}\right)$

Overall: $\mathbf{C H}_{3} \mathbf{O H}+{ }^{3}{ }_{2} \mathbf{O}_{2} \rightarrow \mathbf{2} \mathbf{H}_{2} \mathbf{O}+\mathbf{C O}_{\mathbf{2}}\left(E_{\text {cell }}=1.21 \mathrm{~V}\right.$ at 1 bar, $\left.298.15 \mathrm{~K}\right)$

DMFCs producing $<500 \mathrm{~W}$ power and operating in the temperature range of $-20-50^{\circ} \mathrm{C}$ are ideally positioned and urgently required to act as a "disruptive technology" to replace batteries in portable devices (laptops, cellular phones, PDAs, human (e.g. soldier) portable power packs, digital cameras, and power tools) [14,15]; the driver is the ever increasing power demands which, in the immediate future, will surpass levels projected to be achievable with secondary battery technology (e.g. lithium ion batteries). Inconvenient power saving features have already been introduced on some laptops, (e.g. dimming LCD screens when in battery mode, which leads to visibility problems in bright light, i.e. when outdoors etc). It is increasingly believed that portable DMFCs will be the first fuel cells commercially available to the general public; there has been a recent increase in the number of pre-commercial portable devices (e.g. PDAs, laptops) powered by DMFCs that have been demonstrated in the 
press and at conferences (e.g. DMFC powered laptops announced by NEC in 2003). DMFCs are amenable to such applications due to the good energy density (theoretically up to $5-10$ times that of batteries) of liquid methanol $[16,17]$. Another benefit of using DMFCs instead of batteries is "instant" refuelling (also referred to as "hot-refuelling") when utilising a plugin methanol cartridge.

The performance obtained with the direct oxidation of methanol at the anode in a solid polymer DMFC is inferior compared with a PEMFC supplied with pure hydrogen. There are three main reasons for this: (1) With PEMFCs the electrokinetic overpotenial is effectively due solely to the oxygen reduction at the cathode (hydrogen oxidation occurring near reversibly). In contrast, with DMFCs the anode electrokinetics are also sluggish (as it takes 6 electrons to fully oxidise methanol to carbon dioxide and water). (2) The proton transport through the PEM leads to methanol molecules being transported (via electro-osmosis and/or diffusion) from the anode to the cathode. This methanol crossover leads to a mixed (reduced) potential at the cathode and a lowering of the overall fuel cell voltage, with a consequential lowering of cell efficiencies (directly proportional to the cell voltage). (3) Severe electroosmosis of water from the anode to the cathode (of up to $19 \mathrm{H}_{2} \mathrm{O}$ molecules per proton) also occurs with the supply of diluted methanol at the anode of a DMFC (stoichiometrically 1 $\mathrm{H}_{2} \mathrm{O}$ molecule to $1 \mathrm{CH}_{3} \mathrm{OH}$ is required, see Figure 1); this creates very severe flooding at the cathode, introducing large overpotentials due to mass transport effects.

Traditional methods of overcoming the electrokinetic shortfalls include high, usually unsupported, catalyst loadings (prohibitively expensive loads of around $4 \mathrm{mg} \mathrm{cm} \mathrm{cm}^{-2}$ are common $c f .<0.2 \mathrm{mg} \mathrm{cm}^{-2}$ for PEMFCs) at the anode to maximise methanol oxidation; the anode catalysts also commonly involve binary platinum/ruthenium alloys because carbon 
monoxide is a reaction intermediate which will poison platinum-only catalysts (leading to a significant lowering of cell performance over time). Another approach is to raise the DMFC operating temperature to $>150^{\circ} \mathrm{C}$ where the electrokinetics are more facile; this approach is feasible with acid-doped polybenzimidazole membranes (PBI, Scheme 2) which have been reported to retain high proton-conductivity at high temperatures and lower membrane humidification [18-20]; long term stability of these membranes is, however, still a concern, especially when considering that in most reports the acid species is not attached to the polymer backbones. These PBI-based acid electrolytes are being commercially developed by Celanese Ventures $\mathrm{GmbH}$ (an example patent is given in reference [21])

To alleviate the effects of methanol crossover, thick (high resistance) PEMs (typically Nafion ${ }^{(\mathrm{R})}-117$ at $7 \mathrm{mil}\{178 \mu \mathrm{m}\}$ thickness $)$, dilute solutions of methanol $\left(<2 \mathrm{~mol} \mathrm{dm}^{-3}\right.$ in water), and high loadings of unsupported platinum black (again at prohibitively expensive levels of the order of $4 \mathrm{mg} \mathrm{cm}^{-2}$ ) at the cathode are used. Despite this, power performances of $200 \mathrm{~mW} \mathrm{~cm}^{-2}$ can be obtained at cell potentials of $0.5 \mathrm{~V}$ with a DMFC when operated at $120^{\circ} \mathrm{C}$, a methanol concentration of $0.5 \mathrm{~mol} \mathrm{dm}^{-3}$, catalysts loadings of $>2 \mathrm{mg} \mathrm{cm}^{-2}$, and back pressures of 2 atm at the cathode [22]. Peak power performances have attained around 300 $\mathrm{mW} \mathrm{cm}{ }^{-2}$ [23]. A detailed review of the current status of DMFC research and development is given by Aricò et al. [24], while a discussion of the aging mechanisms and lifetimes of DMFCs (and PEMFCs) has been given by Knights et al. [25].

As already mentioned, these DMFC power densities are well below those obtained with PEMFCs. There is still much research being undertaken to maximise DMFC performance by optimising the structure and loading (especially lowering) of platinum-based electrocatalysts [26]. There is also some research into alternative methanol-resistant cathode catalysts, an 
example of which is carbon supported Pt-Fe alloys [27,28]. However, the authors of this review (along with others $[29,30]$ ) firmly believe that for more substantial increases in DMFC performances, a more radical approach is required.

One innovative approach being investigated by Scott et al. (Newcastle, U.K.) is the mixedreactants solid polymer DMFC [30]; this approach seeks to simplify fuel cell design by relying on selective catalysts to separate the electrochemical oxidation of methanol and reduction of oxidant without physical separation of the fuel and oxidant; initial operation with unoptimised conditions has yielded performances of $50 \mathrm{~mW} \mathrm{~cm}{ }^{-2}$ and $20 \mathrm{~mW} \mathrm{~cm}^{-2}$ at $90^{\circ} \mathrm{C}$ with methanol/oxygen and methanol/air respectively. Another approach, which is the main subject of this article, involves the use of alkaline anion-exchange membranes (AAEMs); this approach combines the advantages of PEMFCs (simple all solid-state construction), AFCs (facile electrokinetics) and DMFCs (high energy density of the fuel), while also minimising disadvantages of each type.

\section{Potential Benefits and Disadvantages of the Use of Alkaline Anion-Exchange Membranes (AAEMs) in a DMFC.}

Alkaline fuel cells (AFCs, which in this review are considered to mean hydrogen-fuelled cells with a liquid electrolyte such at $\mathrm{KOH}(\mathrm{aq})$ ) are the best performing of all known fuel cells (AFCs, PEMFCs, and DMFCs) operable below $200^{\circ} \mathrm{C}$. This is mainly due to the facile kinetics at the cathode as well as at the anode; cheaper non-noble metal catalysts can be used (such as nickel and silver [31-33]), reducing cost. McLean et al. give a recent comprehensive review of alkaline fuel cell technology [34]. 
The fuel cell reactions for a traditional AFC and a hydrogen-fuelled alkaline membrane fuel cell (Figure $1 b)$ are described below:

Anode: $\mathbf{2} \mathbf{H}_{\mathbf{2}}+\mathbf{4} \mathbf{O H}^{-} \rightarrow \mathbf{4} \mathbf{H}_{\mathbf{2}} \mathbf{O}+\mathbf{4 e}^{-}\left(E_{a}=0.83 \mathrm{~V}\right.$ vs. SHE at 1 bar, $\left.298.15 \mathrm{~K}\right)$

Cathode: $\mathbf{O}_{\mathbf{2}}+\mathbf{2} \mathbf{H}_{2} \mathbf{O}+\mathbf{4 e}^{-} \rightarrow \mathbf{4} \mathbf{O H}^{-}\left(E_{c}=0.40 \mathrm{~V} v s\right.$. SHE at 1 bar, $\left.298.15 \mathrm{~K}\right)$

Overall: $\mathbf{2} \mathbf{H}_{2}+{ }^{1} / \mathbf{O}_{2} \rightarrow \mathbf{2} \mathbf{H}_{2} \mathbf{O}\left(E_{\text {cell }}=1.23 \mathrm{~V}\right.$ at 1 bar, $\left.298.15 \mathrm{~K}\right)$

One of the main issues with traditional AFCs is that of electrolyte and electrode degradation caused by the formation of carbonate/bicarbonate $\left(\mathrm{CO}_{3}{ }^{2-} / \mathrm{HCO}_{3}{ }^{-}\right)$in the liquid alkaline electrolyte on reaction of $\mathrm{OH}^{-}$ions with $\mathrm{CO}_{2}$ contamination in the oxidant gas stream $[34,35,36]$. This has limited the application of such fuel cell systems in which pure oxygen can be supplied e.g. the fuel cells currently used on NASA's space shuttle orbiter (there are plans to replace the AFCs with PEMFCs). Nevertheless, Kordesch operated an AFC-powered car daily, with partial scrubbing of the air using soda lime and with replacement of the liquid electrolyte every few hundred operational hours. The major cause of the degrading performance on $\mathrm{CO}_{3}{ }^{2-} / \mathrm{HCO}_{3}{ }^{-}$formation is the precipitation of large solid metal carbonate crystals (most commonly $\mathrm{Na}_{2} \mathrm{CO}_{3}$ or $\mathrm{K}_{2} \mathrm{CO}_{3}$, depending on the alkaline electrolyte used) in the electrolyte-filled pores of the electrodes; these crystals not only block the pores but also mechanically disrupt and destroy the active layers.

The formation of carbonate / hydrogen carbonate are as below:

$\mathrm{CO}_{2}+2 \mathrm{OH}^{-} \rightarrow \mathrm{CO}_{3}{ }^{2-}+\mathrm{H}_{2} \mathrm{O}$

$\mathrm{CO}_{2}+\mathrm{OH}^{-} \rightarrow \mathrm{HCO}_{3}^{-}$

Methanol produces $\mathrm{CO}_{2}$ on electro-oxidation and so $\mathrm{CO}_{3}{ }^{2-} / \mathrm{HCO}_{3}{ }^{-}$formation can be even more of a problem when a methanol fuel cell is operated with a liquid alkaline electrolyte. 
Methanol has been operated in alkaline fuel cells in the past. An example is a methanol fuel cell operating with aqueous $\mathrm{KOH}\left(6 \mathrm{~mol} \mathrm{dm}^{-3}\right)$ by Murray and Grimes [37]. Performances at $0.3 \mathrm{~V}$ decreased steadily over $70 \mathrm{~h}$ at $60^{\circ} \mathrm{C}$ and $94 \mathrm{~h}$ at $30^{\circ} \mathrm{C}$, mainly due to anode degradation. A 40-cell module, with a total electrode area of $480 \mathrm{~cm}^{2}$ and operated at $49^{\circ} \mathrm{C}$ and gas pressures of up to $5 \mathrm{psi}$, produced $440 \mathrm{~W}\left(917 \mathrm{~mW} \mathrm{~cm}^{-2}\right)$ at $0.4 \mathrm{~V}$ and a maximum power output of $730 \mathrm{~W}$ at $0.25 \mathrm{~V}$ with pure oxygen as oxidant. A recent short review by Koscher and Kordesch details past and present work involving alkaline methanol-air systems with liquid caustic electrolytes and emphasises the design of effective electrode structures [38].

The fuel cell equations for the direct use of methanol with an alkaline electrolyte are (Figure $1 b)$ :

Anode: $\mathbf{C H}_{3} \mathbf{O H}+\mathbf{6 O H}^{-} \rightarrow \mathbf{C O}_{\mathbf{2}}+\mathbf{5} \mathbf{H}_{2} \mathbf{O}+\mathbf{6} \mathbf{e}^{-}\left(E_{a}=0.81 \mathrm{~V} v s\right.$. SHE at 1 bar, $\left.298.15 \mathrm{~K}\right)$

Cathode: ${ }^{3} / \mathbf{2}_{\mathbf{2}} \mathbf{O}_{\mathbf{2}}+\mathbf{3} \mathbf{H}_{\mathbf{2}} \mathbf{O}+\mathbf{6} \mathbf{e}^{-} \rightarrow \mathbf{6 O H}^{-}\left(E_{c}=0.40 \mathrm{~V} v\right.$ s. SHE at 1 bar, 298.15 K)

Overall: $\mathbf{C H}_{\mathbf{3}} \mathbf{O H}+{ }^{\mathbf{3}} \mathbf{2}_{\mathbf{2}} \mathbf{O}_{\mathbf{2}} \rightarrow \mathbf{2} \mathbf{H}_{\mathbf{2}} \mathbf{O}+\mathbf{C O}_{\mathbf{2}}\left(E_{\text {cell }}=1.21 \mathrm{~V}\right.$ at 1 bar, $\left.298.15 \mathrm{~K}\right)$

It is well known that methanol oxidation is more facile in alkaline media $[10,39,40]$. Even if $\mathrm{PtRu}$ is required due to catalyst poisoning by intermediate $\mathrm{CO}$ (absorbed $\mathrm{CO}$ has been detected using FT-IR techniques on pure Pt in alkaline media [41]), CO stripping occurs to a greater extent at lower potentials with PtRu catalysts in alkali (compared to acid) and so allows the use of lower loadings of PtRu (compared with traditional DMFCs) [42]. Encouragingly, the oxidation methanol of carbon-supported nickel has been reported in alkaline media [43]. The use of an AAEM in both AFCs and in alkaline-membrane DMFCs (AMDMFCs) may solve the problems with the use of alkali, while still allowing the electrokinetic advantages of AFCs. Firstly orientation limitations are overcome; the 
conducting species is now in a fixed solid polymer membrane. Secondly, even though there will be some $\mathrm{CO}_{3}{ }^{2-} / \mathrm{HCO}_{3}{ }^{-}$formation at the anode, there are no mobile cations $\left(\mathrm{Na}^{+}\right.$or $\left.\mathrm{K}^{+}\right)$to precipitate solid crystals of metal carbonate to block or destroy the electrode layers; with alkaline membranes the cations are already immobilised on the polymer (often polymer bound benzyltrimethylammonium $\sim \mathrm{C}_{6} \mathrm{H}_{4} \mathrm{CH}_{2} \mathrm{NMe}_{3}{ }^{+}$cation sites, Scheme 3). Finally, as there is no liquid caustic electrolyte present, electrode weeping and component corrosion will also be minimised [35].

The use of AAEMs in DMFCs may allow other advantages. The ion transport within the membrane in an operating AMDMFC will be from the cathode to the anode, opposing the direction of, and hence reducing the level of, methanol crossover from anode to cathode; water will actually be electro-osmotically transported from the cathode to the anode, which is the reverse of the situation found with PEM-based DMFCs. As the water is now produced at the anode and consumed at the cathode, the water management regime is altered and potentially simplified. The two factors above avert the problem of catastrophic flooding at the cathode (from electro-osmosis of water from the anode to the cathode in PEM-based DMFCs) mentioned previously, reducing mass-transport-derived voltage losses.

The larger repertoire of effective electrocatalysts in an alkaline environment would facilitate the search for a methanol-tolerant catalyst for the cathode to reduce the effects of any residual methanol crossover even further; this reduced methanol crossover enables the use of thinner, hence lower resistance, membranes. Another potential consequence of this large number of catalyst options with substitution of the PEM with an AAEM is an extended choice of selective catalysts for application in mixed reactant-oxidant fuel cells as evaluated by Scott $e t$ al. [30]. A CO-tolerant anode catalyst with lower metal loadings in alkaline media would also 
allow the use of reformed hydrogen with improved performances. Finally, major cost, physical size, and machinability concerns with traditional graphite-based bipolar plates have stimulated research into thinner, cheaper, and more easily machined metal bipolar plates (such as stainless steels) [44-46]. There are, however, significant corrosion problems associated with such metal plates and acidic PEMs. The replacement of the acidic membranes with alkaline membranes will potentially reduce such corrosion problems and allow cheaper metals to be used (nickel current collectors are already used in traditional AFCs [47]).

A widely quoted concern with anion-exchange membranes (AEMs) is membrane stability in the alkaline forms, especially at elevated temperatures $[48,49]$. Instability is mainly due to the displacement of the ammonium group by the $\mathrm{OH}^{-}$anions (an excellent nucleophile) via (a) a direct nucleophillic displacement and/or (b) a Hofmann elimination reaction when $\beta$ hydrogens are present (Scheme 3); methyl $\left(\mathrm{CH}_{3}\right)$ groups may also be displaced by $\mathrm{OH}^{-}$ions forming tertiary amines and methanol $[48,49]$. However, as mentioned above, a major application of DMFCs is as power sources for portable devices; such fuel cells must be operated at low temperatures, ideally below $60^{\circ} \mathrm{C}$, which means such degradation can be minimal. A commercially available (but undisclosed) AAEM containing benzyltrimethylammonium moieties radiation-grafted onto PTFE membranes was stable at up to $60^{\circ} \mathrm{C}$ in aqueous sodium hydroxide $\left(6 \mathrm{~mol} \mathrm{dm}^{-3}\right)$ [50]; this stability in such a caustic environment demonstrates stability can be adequate for the above proposed application.

\section{Review of the Application of AAEMs in Fuel Cells}

As mentioned above, acid-doped PBI membranes (Scheme 2) allow higher temperature operation of DMFCs and lessen electrokinetic performance losses. PBI can also be doped 
with alkaline salts and such membranes have been applied to hydrogen fuel cells by Xing and Savadogo [51]. PBI doped with various alkali metal hydroxides exhibited conductivities in the range $5 \times 10^{-5}-10^{-1} \mathrm{~S} \mathrm{~cm}^{-1}$. Conductivities approaching $10^{-1} \mathrm{~S} \mathrm{~cm}^{-1}$ were obtained with PBI treated with $\mathrm{KOH}\left(\mathrm{aq}, 6 \mathrm{~mol} \mathrm{dm}^{-3}\right.$ ) at $70-90^{\circ} \mathrm{C}$. The conductivities dropped when increasing amounts of metal carbonates were added to the alkaline doping solution; the mechanism of conductivity was suspected of changing on addition of metal carbonates, and it was reported that this was to be further investigated by those authors.

A $\mathrm{H}_{2} / \mathrm{O}_{2}$ fuel cell was constructed $\left(6.25 \mathrm{~cm}^{2}\right.$ electrode area) and tested with a $\mathrm{KOH}$-doped PBI membrane of thickness $40 \mu \mathrm{m}$ at $50^{\circ} \mathrm{C}$ with an anode and cathode catalyst loading of $0.35 \mathrm{mg} \mathrm{cm}^{-2}$ (from 20\%wt Pt supported on C). Neither gas was humidified and the $\mathrm{H}_{2} / \mathrm{O}_{2}$ pressure ratio was $3 / 5$, while $\mathrm{O}_{2}$ and $\mathrm{H}_{2}$ flow rates were $800 \mathrm{~cm}^{3} \min ^{-1}$ and $1200 \mathrm{~cm}^{3} \mathrm{~min}^{-1}$ respectively. At $0.60 \mathrm{~V}$ cell voltage, a current of $620 \mathrm{~mA} \mathrm{~cm}$-2 was achieved, which corresponds to a power density of $370 \mathrm{~mW} \mathrm{~cm} \mathrm{~cm}^{-2}$. This performance was similar to that of the same apparatus with a Nafion ${ }^{\circledR}-117$ membrane and also, remarkably, with a $\mathrm{KOH}-$ and $\mathrm{K}_{2} \mathrm{CO}_{3}$-doped PBI membrane; this last result is encouraging with respect to application of such AAEMs in fuel cells. As a further comparison, current density at $0.60 \mathrm{~V}$ cell voltage for a PEMFC constructed with sulfuric-acid-doped PBI and testing on the same apparatus was $810 \mathrm{~mA} \mathrm{~cm}^{-2}$, corresponding to a power density of $490 \mathrm{~mW} \mathrm{~cm}{ }^{-2}$.

Fauvarque et al. have evaluated two alkaline AEMs in a $\mathrm{H}_{2} / \mathrm{O}_{2}$ AFC [52,53]. Membrane 1 was a polymer denoted H55 (epichlorhydrine polymer) that was quaternised with 1,4diazabicyclo[2,2,2]octane (DABCO) and membrane 2 was the same polymer quaternised with a 1:1 ratio of $\mathrm{DABCO}$ and triethylamine. The membranes were observed to deteriorate when immersed in $\mathrm{KOH}(\mathrm{aq})$ at concentrations $>1 \mathrm{~mol} \mathrm{dm}^{-3}$. The ion-exchange capacity 
(IEC) was reported to be in the range $0.5-0.6 \mathrm{meq}^{-1}$, which is lower than the IEC of a commercial membrane (Solvay Type ADP). The intrinsic conductivity of membrane 2 in water was $5 \times 10^{-5}-10^{-4} \mathrm{~S} \mathrm{~cm}^{-1}$; these conductivities increased to around $10^{-2} \mathrm{~S} \mathrm{~cm}^{-1}$ when the membrane absorbed further $\mathrm{KOH}(\mathrm{aq})$. Anion transport numbers were determined to be between 0.95 and 0.99 .

The performances of $\mathrm{H}_{2} / \mathrm{O}_{2}$ AFCs with the above membranes are as follows. Electrodes were prepared with $\mathrm{Pt}$ loadings of $0.13 \mathrm{mg} \mathrm{cm}^{-2}$ supported on carbon, and the fuel cell was operated at $25^{\circ} \mathrm{C}$ with gases supplied at atmospheric pressure, which are the conditions of interest for application in portable devices. A maximum power density of $20 \mathrm{~mW} \mathrm{~cm}$-2 was obtained with membrane 2 . The performance of membrane 1 was inferior. For membrane 2, the testing was repeated, but this time an interfacial solution was added between the electrodes and the AAEM; the maximum power density increased to $43 \mathrm{~mW} \mathrm{~cm}{ }^{-2}$. Fauvarque et al. also reported extended work on the electrode-AAEM interface [54]. The interface materials studied were: (1) aqueous alkaline solutions absorbed onto a polyamide film, (2) a solution of the prepared film, (3) an alkaline-gel based on a mixture of polyacrylic acid and potash, and (4) other unspecified interfaces; no results were, however, described in the published extended abstract of that presentation.

Ogumi et al. have studied direct alcohol fuel cells (methanol and ethylene glycol) constructed with a commercial membrane (AHA of ammonium type, Tokuyama Co, Japan; thickness $\approx$ $240 \mu \mathrm{m}$ when in the $\mathrm{Cl}^{-}$form) [55]. The IEC of this membrane was $1.15-1.25 \mathrm{meq} \mathrm{g}^{-1}$ in the $\mathrm{OH}^{-}$form. A membrane electrode assembly (MEA) with the AHA membrane was constructed with carbon-supported platinum at loadings of $1 \mathrm{mg} \mathrm{cm}^{-2}$ and $5 \mathrm{mg} \mathrm{cm}^{-2}$ for the cathode and anode respectively. The MEA was pressed at room temperature at $140 \mathrm{~kg} \mathrm{~cm}^{-2}$ 
for $3 \mathrm{~min}$. Solutions of ethylene glycol and methanol were made to a concentration of $1 \mathrm{~mol}$ $\mathrm{dm}^{-3}$ dissolved in $\mathrm{KOH}\left(\mathrm{aq}, 1 \mathrm{~mol} \mathrm{dm}{ }^{-3}\right.$ ). Fuel cell testing was conducted at $50^{\circ} \mathrm{C}$ with oxygen at unspecified pressures and stoichiometries. Despite using pure $\mathrm{Pt}$ for the anode (not $\mathrm{Pt} / \mathrm{Ru}$ ), anode potentials were reported as $0.41 \mathrm{~V}$ and $0.33 \mathrm{~V}$ at a current density of $20 \mathrm{~mA} \mathrm{~cm} \mathrm{c}^{-2}$ respectively for methanol and ethylene glycol. Cell voltages were around $100 \mathrm{mV}$ higher for ethylene glycol compared to methanol. Maximum power densities were 9.2 and $5.5 \mathrm{~mW} \mathrm{~cm}{ }^{-2}$ respectively for ethylene glycol and methanol; the power densities with methanol are inferior to those recorded at lower temperatures by Agel et al. above. This fuel cell is not quite an alkaline analogue of a PEMFC, as the authors added alkaline solution into the system. Ethylene glycol is an interesting candidate fuel (see Table 1); no indication was given concerning completeness of oxidation of the ethylene glycol to $\mathrm{CO}_{2}$ and $\mathrm{H}_{2} \mathrm{O}$ in this study. The possibilities when operating fuel cells with AAEMs and organic fuels other than methanol are discussed further below.

$\mathrm{Yu}$ and Scott reported the operation of a direct methanol alkaline fuel cell with platinised titanium mesh anodes $\left(1.5 \mathrm{mg} \mathrm{cm}^{-2} \mathrm{Pt} / \mathrm{Ti}\right)$ and a commercial alkaline anion-exchange membrane (Morgane ADP membrane from Solvay S. A.) [56]. The electrochemistry of the mesh electrodes in alkali was explored in a previous publication [57]. The cathode consisted of platinum on carbon (loading of $2 \mathrm{mg} \mathrm{cm}^{-2}, 60 \% \mathrm{wt}$. Pt/C) painted onto a teflonised Ketjen black gas diffusion layer and Toray carbon paper backing layer. The cell $\left(4.9 \mathrm{~cm}^{2}\right.$ active area) was operated at $60^{\circ} \mathrm{C}$; the methanol solution was made to a concentration of $2 \mathrm{~mol} \mathrm{dm}^{-3}$ in aqueous sodium hydroxide $\left(1 \mathrm{~mol} \mathrm{dm}{ }^{-3}\right)$ and supplied at 1 bar pressure and with a flow rate of

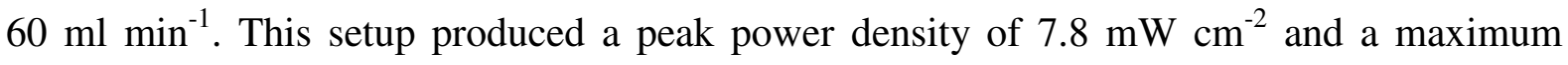
current density of $65 \mathrm{~mA} \mathrm{~cm} \mathrm{~cm}^{-2}$ at short circuit; the same cell operated with an anode consisting of $\mathrm{Pt} / \mathrm{C}\left(1.5 \mathrm{mg} \mathrm{cm}^{-2}\right)$ on non-teflonised Toray produced a peak power density of 
$7.0 \mathrm{~mW} \mathrm{~cm}$ and a maximum current density of $59 \mathrm{~mA} \mathrm{~cm}^{-2}$ at short circuit. While the performance of both setups were comparable at open circuit and at high current densities, at low current densities $\left(<10 \mathrm{~mA} \mathrm{~cm}^{-2}\right)$ the platinised titanium mesh was superior indicating lower activation losses at the anode. No deterioration in fuel cell performance over a period of $48 \mathrm{~h}$ was observed with the platinised titanium mesh anodes. The addition of alkaline species to the aqueous methanol anode stream may well assist in the prevention of $\mathrm{CO}_{3}{ }^{2-}$ $/ \mathrm{HCO}_{3}{ }^{-}$formation in the alkaline membrane.

Zhuang et al. recently conducted a feasibility analysis of the use of AAEMs in DMFCs [58]; this important study concentrated on the thermodynamic disadvantages versus kinetic advantages of such AMDMFCs by studying the reactions taking place in aqueous solutions. The authors, on examining the reaction mechanism, showed a large $\mathrm{pH}$ difference would be created in the AAEM between the anode, (where $\mathrm{CO}_{2}{ }^{2-} / \mathrm{HCO}_{3}{ }^{-}$is formed from reaction of the AAEM with the $\mathrm{CO}_{2}$ produced from oxidation of methanol) and the cathode (where very little $\mathrm{CO}_{2}{ }^{2-} / \mathrm{HCO}_{3}{ }^{-}$is found due to continuous production of $\mathrm{OH}^{-}$ions). It was calculated that at $20^{\circ} \mathrm{C}$, a pH difference of 6.1 would exist corresponding to a thermodynamic voltage loss of ca. $360 \mathrm{mV}$; at $80^{\circ} \mathrm{C}$ the $\mathrm{pH}$ difference drops to 4.1 resulting in a reduced voltage loss of $c a$. $290 \mathrm{mV}$. The authors also demonstrated that, with operation of an AMDMFC at $80^{\circ} \mathrm{C}$ at a current density of $100-200 \mathrm{~mA} \mathrm{~cm}{ }^{-2}$, a voltage gain of $100 \mathrm{mV}$ due to improved electrode kinetics would be obtained at the anode, and a further gain of $100 \mathrm{mV}$ would be obtained at the cathode. If methanol crossover were suppressed, as is hoped with an AMDMFC system, another voltage gain will arise. The authors concluded that the thermodynamic voltage losses found for an AMDMFC, due to the $\mathrm{pH}$ difference across the AAEM, would be roughly cancelled out by the kinetic voltage gains and that operation at elevated temperatures would reduce thermodynamic voltage losses (this may be challenging with respect to AAEM 
stability). Finally, from infrared studies of the reactions in solution reported in the same article, it was shown that methanol could be completely oxidised to $\mathrm{CO}_{2}$ and water in the presence of $\mathrm{CO}_{2}{ }^{2-} / \mathrm{HCO}_{3}{ }^{-}$, which is an important and encouraging finding.

\section{Review of Other Relevant AAEM Systems}

The recent fuel cell studies with AAEMs (reviewed above) show promising initial results on what are unoptimised membranes, MEAs, and/or fuel cell operating conditions. This section describes work on other AAEMs that may be applicable to $\mathrm{H}_{2} / \mathrm{O}_{2}$ and methanol fuel cells, including recent work in our laboratory.

There is extensive worldwide research being conducted on replacement proton exchange membranes (PEMs) [59,60]; the main problems with current generation PEMs (such as Nafion $^{\circledR}$ ) are high methanol permeabilities and fiscal cost. A significant proportion of recent fuel cell membrane research involves the radiation-grafting of styrene onto low and high density polyethylene films (LDPE, HDPE), partially fluorinated films such as poly(vinylidene fluoride) (PVDF) and poly(ethylene-co-tetrafluoroethylene) (ETFE), and fully fluorinated poly(tetrafluoroethylene-co-hexafluoropropylene) (FEP) films; subsequent sulfonation yields cation-exchange sites (sulfonic acid groups) [61-64]. The properties and compositions of the final materials are easily controlled via alteration of the grafting and sulfonation conditions [61,62]. Reviews by Hill et al. describes the radiation chemistry of fluoropolymers [65] and the high energy radiation-grafting of monomers onto fluoropolymers [66]. A very comprehensive review on the preparation of ion-exchange membranes using radiation-grafting of polar monomers onto non-polar films has been recently published by Nasef et al. [67]. Radiation-grafted PEMs have been tested in DMFCs by Scott et al. [68]. 
Radiation-grafted PVDF-based cation-exchange membranes (CEMs) and AEMs produced at Surrey have also been applied to salt-splitting technologies in joint studies with Newcastle University [69-71]. Radiation grafting methodology produces ionomer membranes cheaply and has major advantages in that preformed commercial polymer films are modified, alleviating the need for film formation steps, with the wealth of adjustable experimental parameters (e.g. radiation dose, temperature, film thickness) allowing a large degree of tailorability.

Anion-exchange membranes, formed using the radiation-grafting synthetic route, have in the past been developed for electrodialysis [72,73] and ion-exchange applications [74]. Svarfar et al. have studied radiation-grafted PVDF AEMs for medical applications [75]. Recent studies in our materials chemistry laboratories at Surrey have concentrated on producing and optmising stable and conductive AAEMs in the same way (Scheme 4). Extensive solid-state NMR and vibrational spectroscopic studies showed that PVDF was an unsuitable base polymer for producing AAEMs due to lack of backbone stability when converted to the $\mathrm{OH}^{-}$ forms [76,77]; therefore, caution is advised with the use of the PVDF-based AEMs mentioned above if any trace of alkali is present. FEP was the base material of choice and was grafted with vinylbenzyl chloride (VBC); subsequent amination and alkali anionexchange yielded the desired AAEMs. Using Raman-microscopy, it was shown that the grafting of VBC progressed throughout the thickness of the FEP (referred to as graft penetration, see Figure 2). AAEMs were obtained with IECs of up to $0.96 \mathrm{meq} \mathrm{g}^{-1}$ in the $\mathrm{Cl}^{-}$ forms and these AAEMs show good conductivities of the order of magnitude of $10^{-2} \mathrm{~S} \mathrm{~cm}^{-1}$ in the exchanged $\mathrm{OH}^{-}$forms. Monitoring the IEC of an example membrane with time while heating in water (open to air and therefore traces of $\mathrm{CO}_{2}$ ) at $60^{\circ} \mathrm{C}$ demonstrated good ex situ 
membrane stability over a period of $2500 \mathrm{~h}$ (Figure 3); this temperature is effectively an upper limit for operating fuel cells in portable devices.

The diffusion coefficient of $\mathrm{OH}^{-}$ions is less than that of protons [52] in nearly all media, so it is essential to maximise IECs to get conductivities as high as possible with AAEMs. It is also essential that the effect of the reaction conditions on the membranes produced is explored in detail for each parent polymer film / monomer combination [62]. Further studies were undertaken at Surrey with these two aims in mind [78]: FEP can be grafted with VBC with degrees of grafting (DOG) of at least 29\% (by mass), with the graft penetration improving on increasing DOG; membranes with improved IECs $\left(\mathrm{Cl}^{-}\right.$forms) of up to $1.1 \mathrm{meq} \mathrm{g}^{-1}$ ( $c f$. Nafion ${ }^{\circledR} 11 \mathrm{x}$-series of membrane have IECs of $0.91 \mathrm{meq}^{-1}$ ) were produced, which exhibited conductivities $\left(\mathrm{OH}^{-}\right.$forms) of $\sim 10^{-2} \mathrm{~S} \mathrm{~cm}^{-1}$ (initial 2-probe impedance spectroscopy measurements); however, further improvements in grafting levels (and hence IECs) are required to get conductivities at levels equivalent to current PEMs. Fuel cell measurements of these radiation-grafted AAEMs (RG-AAEMs) are now commencing alongside in situ impedance spectroscopy measurements to confirm membrane conductivities and electrode overpotentials.

There are many reports of work on different anion-exchange materials in the literature, the majority of which concentrate on applications other than in fuel cells. Childs et al. have studied highly crosslinked AEMs synthesised from poly(vinylbenzyl chloride) quaternised using the diamines DABCO and piperazine $[79,80]$ for various applications, including water softening; the crosslinked anion-exchange polymer phase was supported in the pores of microporous polypropylene and further crosslinking was enabled by subsequent reaction with $\alpha, \alpha^{\prime}$-dibromo- $p$-xylene. A detailed study was conducted by Tomoi et al. concerning the 
synthesis of thermally stable alkaline anion-exchange resins [81]; incorporating a "hexyloxy spacer group" $\left(\mathrm{OC}_{6} \mathrm{H}_{12}\right.$ ether linkage $)$ between the benzyl $\mathrm{CH}_{2}$ carbon and the quaternary ammonium anion-exchange site (Scheme 5) yielded resins which retained $>80 \%$ of their IECs after treatment at $120^{\circ} \mathrm{C}$ for 30 days, and retained $98 \%$ at $100^{\circ} \mathrm{C}$ for the same period of time. If membranes, as opposed to resins, could be made with such functionalities and thermal stabilities, these would be excellent candidates for alkaline membrane fuel cells; at such elevated temperatures, the thermodynamic voltage losses previously mentioned in the feasibility study of Zhuang et al. [58] would be minimised.

Yang et al. produced alkaline poly(vinyl alcohol) / poly(epichlorohydrin) copolymers for application in Zn-air batteries [82]. Arof et al. produced poly(vinyl alcohol)-KOH blend alkaline electrolytes with conductivities $<10^{-5} \mathrm{~S} \mathrm{~cm}^{-1}$ for a nickel-zinc cells [83]. Vargas et al. also studied PVA-KOH electrolytes and obtained conductivities up to $2.3 \times 10^{-3} \mathrm{~S} \mathrm{~cm}^{-1}$ for application in humidity sensors and alkaline batteries [84]. Sun et al. studied highly conductive poly(sodium acrylate) / tetramethylammonium hydroxide blends and mentioned AFCs as a potential application [85]. AEMs produced from a simultaneous amination and crosslinking process were reported by Tongwen et al. for desalination processes, with IECs of the order of $10^{-3} \mathrm{~S} \mathrm{~cm}^{-1}[86,87]$. Bowman et al. [88] and Moon et al. [89] have looked at functionalised poly(vinylbenzyl chloride) and LDPE/polyvinylbenzyltrimethylammonium salt copolymer AEMs respectively, for ion-exchange applications. Sanchez et al. reported the synthesis and characterisation of amorphous anion conducting polyether networks with conductivities between $10^{-9}$ and $10^{-5} \mathrm{~S} \mathrm{~cm}^{-1}$ [90]. A study of the thermal membrane potentials of poly(styrene-co-divinylbenzene) based AEMs containing various trialkylammonium groups was reported by Tasaka et al. [91]. A commercial anion-exchange resin (in alkali form), from Amberlite IRA-900, has been applied in catalysts for the aldol condensation of 
acetone [92]. Polymer-supported onium salts based around vinylbenzyl chloride, and produced using an emulsion polymerisation methodology, have been applied as phase transfer catalysts in the alkylation of isopropylidene malonate [93]. All of these AEMs and resins, however, exhibited conductivities well below levels required for application in fuel cells.

Sata et al. conducted an extensive study on the stability of commercial AEMs from various commercial manufacturers (Tokuyama, Ashai Glass, Pall-RAI etc.) [50]; most of these membranes contained either trimethylammonium or $\mathrm{N}$-methyl pyridinium groups. AEMs were also prepared in this study based on both chloromethylated polysulfone (Scheme 6) and polymerised vinylbenzyl chloride. It was concluded that AAEMs based on trimethylammonium groups were the most stable to treatment in hot alkaline solutions; this conclusion directed the choice of functional group chemistry selected at Surrey for application in alkaline membrane fuel cells. Ohya et al. [94,95] and Hao et al. [96] have also studied AEMs based on chloromethylated polysulfones (Scheme 6) for electrodialysis applications; there is, however, no evidence in the literature that such polysulfone-based AEMs have been applied to fuel cells.

\section{A Brief Survey of the Patent Literature}

This is not intended to be an exhaustive survey of patent applications; there are, however, a small number of patents of interest in relation to alkaline membrane fuel cells. Related patents and patent applications from J. Divisek describe the invention of a methanol fuel cell

utilising an anion-exchange membrane [97-99]. J.-F. Fauvarque was granted a patent on aqueous alkaline solid electrolyte based around polyether polymer matrices [100]. W. Yao, T. 
Tsai, Y.-M. Chang, and M. Chen were granted related patents on alkaline polymers containing alkyl quaternary ammonium salts, nitrogen containing heterocyclic quaternary ammonium salts, and metal hydroxide salt for potential applications in alkaline batteries and fuel cells [101-103]. A patent was issued to F. Jaouen concerning a novel cathode structure for a solid polymer fuel cell [104]; that cathode structure consisted of a solid polymer anionexchange membrane surrounding the catalysts particles (entirely within the cathode structure), which was in contact (surrounded) with a cation-conducting polymer membrane. J. $\mathrm{Lu}$ and L. Zhuang were granted a patent on alkaline-resin-containing fuel cells with direct fuelling with liquid organic fuels [105].

Patents relating to the application of radiation-grafted ion-exchange membranes in fuel cells have been granted to G. G. Scherer, F. N. Büchi, and B. Gupta [106] and to C. Stone and A. Steck [107,108]. All these patents mention the functionalisation of base polymers with quaternary ammonium groups to yield alkaline polymers. The use of fluoro-substituted styrenic monomers is also claimed to improve membrane chemical stability when utilised in fuel cells (removal of undesired and reactive C-H bonds).

\section{Future Research Challenges}

It is evident from all of the above studies that there are a number of research challenges that must be overcome before AAEMs can be successfully applied to pre-commercial fuel cells:

(1) As a priority and to compliment ex situ stability measurements [77] (Figure 3), AAEMs must be evaluated in $\mathrm{H}_{2} / \mathrm{O}_{2}, \mathrm{H}_{2} /$ air, and methanol/air fuel cells for several thousand hours to ensure adequate in situ membrane stability and assess the effect of 
and level of $\mathrm{CO}_{2}{ }^{2-} / \mathrm{HCO}_{3}{ }^{-}$formation. The effect of adding alkali to the methanol solution [56] must also be thoroughly investigated over long timescales.

(2) AAEMs must be created with higher conductivities, to ensure good fuel cell performances at high current densities. It should be noted, however, that with application of an AMDMFC as a power source for portable devices an overriding priority is maximising the energy density of the fuel and fuel efficiency (cell voltage). These DMFCs will be operated at low-to-medium current densities (higher efficiencies), where electrode overpotentials are the dominant cause of voltage losses.

(3) It is also essential that a solublised form of an alkaline anion-exchange polymer be developed to improve the interface between the electrodes and the AAEM electrolyte. Success in this effort will further decrease MEA resistances; the soluble material will be analogous to the commercially available Nafion $^{(\mathrm{R})}$ solutions in water/alcohol mixtures used to optimise MEA interfaces in acid form PEMFCs and DMFCS $[109,110]$. A water-based soluble form which can be rendered water insoluble when cast would be preferred, as there are safety concerns (primarily with industrial scale production) about using organic solvents near finely dispersed (pyrophoric) metal catalysts (unsupported or supported on carbon).

(4) If AAEMs are to be applied to fuel cells for other applications (such as automotive power etc.), more temperature stable AEMs must be developed. Operation of alkalinemembrane-based fuel cells at elevated temperature would reduce thermodynamic voltage losses due to $\mathrm{pH}$ differences across the AAEM [58] and would also improve the electrokinetics. Successful, stable over the long term, operation at elevated temperatures would allow application in fuel cells for the automotive mass-market. 
The article on thermally stable alkaline anion-exchange resins by Tomoi et al. [81] hints at chemistry required in targeting this outcome.

(5) If AAEMs are proven to be stable in fuel cells over 1000's of hours, an in-depth investigation into effective and cheaper non-noble metal catalysts (e.g. $\mathrm{Ni}, \mathrm{Ag}$ etc.) is indicated. There would also be a greater chance of finding methanol-tolerant catalysts for use in the cathodes than in related PEM-based DMFCs.

(6) Another, more technical, challenge will be to measure anode performances and electrokinetics in the fuel cell. Whereas hydrogen can be fed to the cathode with PEM-based DMFCs, to act as a dynamic hydrogen reference electrode (when testing a fuel cell [111] and conducting impedance spectroscopy measurements $[112,113])$ to assist evaluation of anode performances, this cannot be done using an AAEM; that is because oxygen must be present at the cathode to generate the $\mathrm{OH}^{-}$ions. Therefore, a separate reference electrode must be present, adding to the complexity of the test system; this has, however, been carried out with an AAEM in a recent study [55].

(7) Finally, removal of fluorine from the polymer systems would be of interest to enhance the environmental credentials (facilitate easier disposal) and reduce costs. The substitution of fully fluorinated FEP with non-fluorinated LDPE is feasible. While oxidative radical degradation is a problem at the cathode and anode (via oxygen diffusion through the membrane) with non-fluorinated PEMs [114-116] (e.g. the poly(styrene sulfonic acid) PEMs used in the fuel cells for NASA's Gemini space program in the 1960's and other polymers containing benzyl C- $\mathrm{H}_{\alpha}$ bonds, see Scheme 7), it has been shown using electron paramagnetic resonance (EPR) studies that such degradation is prevented in highly alkaline $(\mathrm{pH}>11.7)$ conditions intrinsic to AAEMs [114]. 


\section{Feasibility of Alternative Fuels Coupled with the Application of AAEMs in Fuel Cells}

There is considerable interest in evaluating organic fuels other than methanol in fuel cells, especially if full and facile electro-oxidation can be achieved. Methanol is toxic, while alcohols such as ethanol are less so. The direct use of "higher" alcohols is of interest due to potentially higher energy densities and higher maximum thermodynamic efficiencies $[9,10]$ (Table 1). The use of ethanol would be especially attractive due to its availability from renewable sources such as the fermentation of sugar-containing raw materials (Brazil already distributes ethanol through the gas station network to fuel internal combustion powered cars); concentrated ethanol solutions up to $40 \%$ by weight in open containers have already been cleared by the various aviation authorities for use in aircraft cabins (relevant for lap-top computer / PDA power supplies). Incredibly, there has recently been a US\$400,000 investment by seed-capital company BioGenerator jointly with a US\$250,000 investment by St. Louis University into a project to develop biofuel cells fuelled with vodka, beer and other ethanol-based substances [117].

There have been many recent reports concerning the operation of PEM-based direct alcohol fuel cells (DAFCs) with "higher" alcohols such as propanol and ethanol. It has been reported $[9,10,118]$ that ethanol gives similar performances to methanol at high operating temperatures with acidic membranes. A further point of interest is that $\mathrm{Pt} / \mathrm{Sn}$ anode catalysts are more active than $\mathrm{Pt} / \mathrm{Ru}$ in the case of direct fuelling with ethanol [119-121] in cells with acidic membranes. CuNi-modified $\mathrm{Pt} / \mathrm{Ru}$ have shown superior ethanol oxidation in alkaline media [122]. However, complete electrooxidation of ethanol has still not been achieved. 
In contrast, complete oxidation (C-C bond cleavage) of ethylene glycol in a proton-exchange membrane fuel cell has been claimed [123]. It has also been reported that the electroactivity of ethylene glycol (EG) in alkaline media is high [124]. Ethylene glycol has an existing production and distribution infrastructure in place (as anti-freeze) and could be a promising fuel for portable devices. As reported above, Ogumi et al. have conducted preliminary studies on the use of a commercially available AAEM in direct alcohol fuel cells [55]; superior performance and power densities were reported when ethylene glycol was used, compared with methanol, but no investigation into the degree of oxidation of EG or into the oxidation products was conducted. Vielstich et al. have studied the electrocatalysis of EG with $\mathrm{Pt} / \mathrm{Ru}$ catalysts showing good activity [125]; by-products such as oxalic acid and glycolic acid from incomplete oxidation of EG were detected. Fuel cell measurements at $70^{\circ} \mathrm{C}$ using Nafion ${ }^{(\mathrm{R})}$ and $\mathrm{Pt} / \mathrm{Ru}$ catalysts at the anode also showed that crossover of EG to the cathode and/or oxidation products leads to a substantial decrease in the cathode potential; a conclusion of the report was that new alternative membranes are required to effectively use EG in direct alcohol fuel cells.

Umeda et al. concluded [126] that the use at ambient temperature of 2-propanol (aq, $0.5 \mathrm{~mol}$ $\mathrm{dm}^{-3}$ ) produced better performances than methanol at low current densities, while more concentrated 2-propanol (aq, $5 \mathrm{~mol} \mathrm{dm}^{-3}$ ) produced superior performance to methanol at all current densities; performances were, however, poor compared with state-of-the-art DMFCs, and 2-propanol produced acetone as the only product (incomplete oxidation), which tended to accumulate around the anode, reducing performance. Qi and Kaufman reported [127] high performance at temperatures below $80^{\circ} \mathrm{C}$, particularly at low current densities, with the use of undiluted 2-propanol and an S-PEEK (sulfonanted polyetheretherketone) PEM; an example performance at $80^{\circ} \mathrm{C}$ (pure 2-propanol at the anode) with an air flow rate at the cathode of 
$870 \mathrm{~cm}^{3} \mathrm{~min}^{-1}$ gave a cell voltage of $0.485 \mathrm{~V}$ at a current density of $200 \mathrm{~mA} \mathrm{~cm} \mathrm{~cm}^{-2}$ (corresponding to $97 \mathrm{~mW} \mathrm{~cm}^{-2}$ ). Superior performance and low fuel-crossover with 2propanol, compared to methanol, was also reported when a Nafion ${ }^{\circledR}$ PEM was used [128]. These performances at low current densities and temperatures, located in the operating regime for portable devices, suggests the direct use of this fuel could be applicable to such applications, but poisoning of the anode by intermediate oxidation products reduces performance at high current densities and reduces the intrinsic fuel energy density (the cell self-refreshed, however, on being shutdown).

The challenge for AAEMs in this arena is to enable catalysts to be found that, in conjunction with the alkaline environment, allow complete oxidation to maximise the energy extracted from these alcohols; if ethanol is to be used as feed, it is important to get good performance at lower temperatures if the benefits of using this fuel (infrastructure and renewability) are to be conferred onto fuel cells for portable devices.

Three alternative (non-alcoholic) fuel vectors are of interest with respect to alkaline membrane fuel cells. Firstly, Yasuda et al. have studied the application of AEMs in a hydrazine fuel cell [129]; hydrazine $\left(\mathrm{H}_{2} \mathrm{NNH}_{2}\right.$, theoretical mass energy density of $2.6 \mathrm{~kW} \mathrm{~h} \mathrm{~kg}{ }^{-1}$ [121]), once used as rocket fuel with associated interesting safety considerations and corrosive properties) is alkaline in aqueous solution and is expected to be highly compatible with an AAEM. A now commercially unavailable AEM (Tosflex ${ }^{\circledR}$ SF-17, Tosoh, $175 \mu$ m thick) was attached to Pt electrodes by electroplating to a Pt loading of $1 \mathrm{mg} \mathrm{cm}^{-2}$. A $10 \mathrm{~cm}^{2}$ single cell heated to $70^{\circ} \mathrm{C}$ was constructed, an aqueous solution of hydrazine $\left(2 \mathrm{~mol} \mathrm{dm}{ }^{-3}\right)$ was supplied to the anode at $2 \mathrm{~cm}^{3} \mathrm{~min}^{-1}$ and humidified oxygen was supplied to the cathode at $400 \mathrm{~cm}^{3}$ $\min ^{-1}$. A current density of around $20 \mathrm{~mA} \mathrm{~cm}^{-2}$ was obtained at a cell potential of $0.4 \mathrm{~V}$, 
corresponding to a power density of $8 \mathrm{~mW} \mathrm{~cm}^{-2}$; this performance was vastly superior to comparable use of a PEM in a direct hydrazine fuel cell.

Secondly, there is the direct borohydride $\left(\mathrm{BH}_{4}{ }^{-}\right)$fuel cell. Binder et al. reported a sodium borohydride / air fuel cell utilising an AAEM (2259-60 Pall RAI) [130]. The maximum cell voltage obtainable with the sodium borohydride / oxygen couple $\left(\mathrm{BH}_{4}^{-}+2 \mathrm{O}_{2} \rightarrow \mathrm{BO}_{2}{ }^{-}+\right.$ $2 \mathrm{H}_{2} \mathrm{O}$ ) is $1.64 \mathrm{~V}$ and the theoretical maximum energy density is $9.3 \mathrm{~kW} \mathrm{~h} \mathrm{~kg}^{-1}$. A commercial gas diffusion electrode (Johnson Matthey) was used at the cathode, while carbon silks deposited with gold and gold/platinum particles were used as anode materials. Maximum power densities were obtained with a $3 \% \mathrm{Pt} / 97 \% \mathrm{Au}$ mix dispersed on the carbon silk (at $0.4 \mathrm{~V}$ cell voltage $20 \mathrm{~mW} \mathrm{~cm}^{-2}$ was obtained at room temperature and $63 \mathrm{~mW} \mathrm{~cm}^{-2}$ at $70{ }^{\circ} \mathrm{C}$ ). However, maximum energy density was obtained with an Au-only-dispersed carbon silk anode (184 $\mathrm{W} \mathrm{h} \mathrm{kg}^{-1}$, undisclosed borohydride concentration). Further experiments with the Au-only anode with a $5 \% \mathrm{NaBH}_{4} / 25 \% \mathrm{NaOH}$ solution demonstrated that $\sim 6.9$ electrons were released per $\mathrm{BH}_{4}{ }^{-}$unit out of a maximum of 8 ; this excellent faradaic efficiency demonstrated low amounts of competing borohydride hydrolysis reactions $\left(\mathrm{BH}_{4}{ }^{-}+2 \mathrm{H}_{2} \mathrm{O} \rightarrow\right.$ $\mathrm{BO}_{2}^{-}+4 \mathrm{H}_{2}$, especially facile at $\mathrm{pH}<7$ ). It was noted that selective anion-exchange membranes would be an advantage to minimise $\mathrm{BH}_{4}{ }^{-}$crossover.

Finally, it has been proposed that ammonia would make a good energy vector / carrier [35] and an indirect fuel for a hydrogen fuel cell; ammonia is environmentally benign (it is already used as a fertiliser and neutralises acid rain), already available cheaply $(\$ 1.2 / \mathrm{kW} \mathrm{h}$ compared with $\$ 3.8$ for methanol and $\$ 25$ for hydrogen), contains $50 \%$ more $\mathrm{H}$ per $\mathrm{dm}^{3}$ than liquid hydrogen, and is a liquid at much lower pressures ( $8-9$ bar); it also has the advantage of a strong smell, allowing the easier location of leaks. However, cracking ammonia to form 
hydrogen for traditional PEMFCs requires temperatures of above $900^{\circ} \mathrm{C}$ to remove all traces of $\mathrm{NH}_{3}$; PEMFCs cannot tolerate any such contamination. The advantage of AFCs is that they can tolerate low levels of $\mathrm{NH}_{3}$ contamination, and so cracking can be undertaken at lower temperatures if hydrogen is to be supplied to such an AFC; this is a final potential benefit of using an alkaline membrane as opposed to an acid form membrane.

\section{Acknowledgements}

We thank the Engineering and Physical Sciences Research Council (EPSRC) for a grant in the field of development of alkaline membrane technology for energy generation (Grant GR/S60709/01).

[1] T. R. Ralph, M. P. Hogarth, Platinum Metals Rev., 2002, 46, 3 - 14.

[2] T. R. Ralph, M. P. Hogarth, Platinum Metals Rev., 2002, 46, 117 - 135.

[3] Z. Qi, A. Kaufmann, J. Power Sources, 2003, 113, 37 - 43.

[4] S. Gamburzev, A. J. Appleby, J. Power Sources, 2002, 107, 5 - 12.

[5] S. Y. Cha, W. M. Lee, J. Electrochem. Soc., 1999, 146, 4055 - 4060.

[6] R. O’Hayre, S. J. Lee, S. W. Cha, F. B. Prinz, J. Power Sources, 2002, 109, 483 - 493.

[7] S. Lister, G. McLean, J. Power Sources, 2004, 130, 61 - 76.

[8] C. A. Schiller, F. Richter, E. Gülzow, N. Wagner, Phys. Chem. Chem. Phys., 2001, 3, $2113-2116$.

[9] C. Lamy, A. Lima, V. LeRhun, F. Delime, C. Coutanceau, J.- M. Leger, J. Power Sources, 2002, 105, $283-296$.

[10] C. Lamy, E. M. Belgsir, J.- M. Leger, J. Appl. Electrochem., 2001, 31, 799 - 809. 
[11] S. Dunn, Int. J. Hydrogen Energy, 2002, 27, 235 - 264.

[12] S. Dunn, Int. J. Hydrogen Energy, 2003, 28, 131 - 133.

[13] C. Stone, A. E. Morrison, Solid State Ionics, 2003, 152 - 153, 1 - 13.

[14] D. Cohen, New Scientist, 19 $^{\text {th }}$ October 2002, 176 issue 2365, 40.

[15] X. Ren, P. Zelenay, S. Thomas, J. Davey, S. Gottesfeld, J. Power Sources, 2000, 86, 111 $-116$.

[16] C. K. Dyer, J. Power Sources, 2002, 106, 31 - 34.

[17] C. Hebling, A. Heinzel, Fuel Cell Bull., July 2002, 8 -12.

[18] P. Jannasch, Curr. Opin. Colloid. Interf. Sci., 2003, 8, 96 - 102.

[19] A. Heinzel, V. M. Barragàn, J. Power Sources, 1999, 84, 70 - 74

[20] Y.-L. Ma, J. S. Wainright, M. H. Litt, R. F. Savinell, J. Electrochem. Soc., 2004, 151, A8 - A16.

[21] US Patent: 6,632,847, 2003, Celanese Ventures GmbH, Germany.

[22] S. C. Thomas, X. Ren, S. Gottesfeld, P. Zelenay, Electrochim. Acta, 2002, 47, 3741 3748.

[23] K. Scott, W. M Taama, J. Cruikshank, J. Power Sources, 1997, 65, 159 -171.

[24] R. Dillon, S. Srinivasan, A. S. Aricò. V. Antonucci, J. Power Sources, 2004, 127, 112 116.

[25] S. D. Knights, K. M. Colbow, J. St-Pierre, D. P. Wilkinson, J. Power Sources, 2004, $127,127-134$

[26] T. R. Ralph, M. P. Hogarth, Platinum Metals Rev., 2002, 46, 146 - 164.

[27] A. K. Shukla, R. K. Raman, N. A. Choudhury, K. R. Priolkar, P. R. Sarode, S. Emura, R. Kumashiro, J. Electroanal. Chem., 2004, 563, 181 - 190. 
[28] W. Li, W. Zhou, H. Li, Z. Zhou, B. Zhou, G. Sun, Q. Xin, Electrochim. Acta, 2004, 49, $1045-1055$.

[29] G.J.K. Acres, J. Power Sources, 2001, 100, 60 - 66.

[30] K. Scott, A. K. Shukla, C. L. Jackson, W. R. A. Meuleman, J. Power Sources, 2004, $126,67-75$.

[31] S. Gamburzev, K. Petrov, A. J. Appleby, J. Appl. Electrochem. , 2002, 32, 805 - 809.

[32] N. Wagner, M. Schulze, E. Gülzow, J. Power Sources, 2004, 127, 264 - 272.

[33] M. Schulze, E. Gülzow, J. Power Sources, 2004, 127, 252 - 263.

[34] G. F. McLean, T. Niet, S. Prince-Richard, N. Djilali, Int. J. Hydrogen Energy, 2002, 27, $507-526$.

[35] M. Cifrain, K. V. Kordesch, J. Power Sources, 2004, 127, 234 - 242.

[36] E. Gülzow, M. Schulze, J. Power Sources, 2004, 127, 243 - 251.

[37] E. Chen in Fuel Cell Technology Handbook, (Ed. G. Hoogers), CRC-PRESS, Boca Raton, 2003, p.2-24 - p.2-25.

[38] G. A. Koscher, K. Kordesch, J. Solid State Electrochem., 2003, 7, 632 - 636.

[39] A. V. Tripković, K. D. Popović, B. N. Grgur, B. Blizanac, P. N. Ross, N. M. Marković, Electrochim. Acta, 2002, 3707 - 3714.

[40] E. H. Yu, K. Scott, R. W. Reeve, J. Electroanal. Chem., 2003, 547, 17 - 24.

[41] A. V. Tripković, N. M. Mannković, K. D. Popović, R. R. Adzic, Russ. J. Electrochem., 1995, $31,993-1003$

[42] J. S. Spendelow, G. Q. Lu, P. J. A. Kenis, A. Wieckowski, J. Electroanal. Chem., 2004, $568,215-224$.

[43] M. A. Abdel Rahim, R. M. Abdel Hameed, M. W. Khalil, J. Power Sources, 2004 in press. 
[44] J. Wind, R. Späh, W. Kaiser, G. Böhm, J. Power Sources, 2002, 105, 256 - 260.

[45] K. Scott, P. Argyropoulos, P. Yiannopoulos, W. M. Taama, J. Appl. Electrochem., 2001, $31,823-832$.

[46] D. P. Davies, P. L. Adcock, M. Turpin, S. J. Rowen, J. Appl. Electrochem., 2000, 30, $101-105$.

[47] P. Gouérec, L. Poletto, J. Denizot, E. Sanchez-Cortezon, J. H. Miners, J. Power Sources, 2004, 129, $193-204$.

[48] A. A. Zagorodni, D. L. Kotova, V. F. Selemenev, React. Funct. Polym., 2002, 53, 157 171.

[49] V. Neagu, I. Bunia, I. Plesca, Polym. Degrad. Stab., 2000, 70, 463 - 468.

[50] T. Sata, M. Tsujimoto, T. Yamaguchi, K. Matsusaki, J. Membr. Sci., 1996, 112, 161 170.

[51] B. Xing, O. Savadogo, Electrochem. Commun., 2000, 2, 697 - 702.

[52] E. Agel, J. Bouet, J. F. Fauvarque, J. Power Sources, 2001, 101, 267 - 274.

[53]E. Agel, J. Bouet, J. F. Fauvarque, H. Yassir, Ann. Chim. Sci. Mater., 2001, 26, 59 - 68.

[54] E. Agel, J. Bouet, J. F. Fauvarque, Extended Abstracts of the $4^{\text {th }}$ International Symposium on New Materials for Electrochemical Systems, (Eds. O. Savadogo), Montréal, July $9^{\text {th }}-13^{\text {th }} 2001$, p. 284 .

[55] Z. Ogumi, K. Matsuoka, S. Chiba, M. Matsuoka, Y. Iriyama, T. Abe, M. Inaba, Electrochemistry, 2002, 70, $980-983$.

[56] E. H. Yu, K. Scott, Electrochem. Commun., 2004, 6, 361 - 365.

[57] E. H. Yu , K. Scott , R. W. Reeve , L. Yang, R. G. Allen, Electrochim. Acta, 2004, 49, $2443-2452$. 
[58] Y. Wang, L. Li, L. Hu, L. Zhuang, J. Lu, B. Xu, Electrochem. Commun., 2003, 5, 662 666.

[59] J. A. Kerres, J. Membr. Sci., 2001, 185, 3 - 27.

[60] P. Jannash, Curr. Opin. Colloid Interf. Sci., 2003, 8, 96 - 102.

[61] K. V. Lovell, J. A. Horsfall, Eur. Polym. J., 2002, 38, 1671 - 1682.

[62] P. Brack, H. G. Buhrer, L. Bonorand, G. G. Scherer, J. Mater. Chem., 2001, 10, 1795 1803.

[63] B. Gupta, F. N. Büchi, G. G. Scherer, J. Poly. Sci.: Part A: Polym. Chem., 1994, 32, $1931-1938$.

[64] J. A. Horsfall, K. V. Lovell, Fuel Cells, 2001, 1, 186 - 191.

[65] J. S. Forsythe, D. J. T. Hill, Prog. Polym. Sci., 2000, 25, 101 - 136.

[66] T. R. Dargaville, G. A. George, D. T. Hill, A. K. Whittaker, Prog. Polym. Sci., 2003, 28, $1355-1376$.

[67] M. M. Nasef, E.-S. A. Hegazy, Prog. Polym. Sci., 2004, 29, 499 - 561.

[68] K. Scott, W. M. Taama, P. Argyropoulos, J. Membr. Sci., 2000, 171, 119 - 130.

[69] N. Tzanetakis, W. M. Taama, K. Scott, J. R. Varcoe, R. C. T. Slade, Desalination, 2003 $151,275-282$.

[70] N. Tzanetakis, W. M. Taama, K. Scott, R. J. J. Jachuck, R. C. T. Slade, J. R. Varcoe, Sep. Puri. Tech., 2003, 30, 113 - 127.

[71] N. Tzanetakis, J. R. Varcoe, R. C. T. Slade, K. Scott, Electrochem. Commun., 2003, 5, $115-119$.

[72] T. Cohen, P. Dagard, J. Molénat, B. Brun, C. Gavach, J. Electroanal. Chem., 1986, 210, $329-336$. 
[73] W. Lee, K. Saito, S. Furusaki, T. Sugo, K. Makuuchi, J. Membr. Sci., 1993, 81, 295 305.

[74] J. Sandeaux, R. Sandeaux, G. Pourcelly, J. Molénat, J. Membr. Sci., 1993, 84, 213 - 227.

[75] B. L. Svarfvar, K. B. Ekman, M. J. Sundell, J. H. Näsman, Polym. Adv. Tech., 1996, 7, $839-846$.

[76] T. N. Danks, R. C. T. Slade, J. R. Varcoe, J. Mater. Chem., 2002, 12, 3371 - 3373.

[77] T. N. Danks, R. C. T. Slade, J. R. Varcoe, J. Mater. Chem., 2003, 13, 712 - 721.

[78] H. Herman, R. C. T. Slade, J. R. Varcoe, J. Membr. Sci., 2003, 218, 147 - 163.

[79] A. K. Pandey, A. Goswami, D. Sen, S. Mazumder, R. F. Childs, J. Membr. Sci., 2003, $217,117-130$.

[80] A. K. Pandey, R. F. Childs, M. West, J. N. A. Lott, B. E. McCarry, J. M. Dickson, J. Appl. Polym. Sci.:Part A: Polym. Chem., 2001, 39, 807 - 820.

[81] M. Tomoi, K. Yamaguchi, R. Ando, Y. Kantake, Y. Aosaki, H, Kubota, J. Appl. Polym. Sci., 1997, 64, $1161-1167$.

[82] C.- C. Yang, S.- J. Lin, S.- T. Hsu, J. Power Sources, 2003, 122, 210 - 218.

[83] A. A. Mohamad, N. S. Mohamed, M. Z. A. Yahya, R. Othman, S. Ramesh, Y. Alias, A. K. Arof, Solid State Ionics, 2003, 156, 171 - 177.

[84] I. Palacios, R. Castillo, R. A. Vargas, Electrochim. Acta, 2003, 48, 2195 - 2199.

[85] J. Sun, D. R. MacFarlane, M. Forsyth, Electrochim. Acta, 2003, 1971 - 1976.

[86] X. Tongwen, F. F. Zha, J. Membr. Sci., 2002, 199, 203 - 210.

[87] X. Tongwen, Y. Weihua, J. Membr. Sci., 2001, 190, 159 - 166.

[88] K. L. Thunhorst, R. D. Noble, C. N. Bowman, J. Membr. Sci., 1997, 128, 183 - 193.

[89] Y.- J. Choi, M.- S. Kang, J. Cho, S.- H. Moon, J. Membr. Sci., 2003, 221, 219 - 231. 
[90] O. Brylev, F. Alloin, M. Duclot, J.-L. Souquet, J.-Y. Sanchez, Electrochim. Acta, 2003, $48,1953-1959$.

[91] M. S. Huda, R. Kiyono, M. Tasaka, T. Yamaguchi, T. Sata, Sep. Puri. Tech., 1998, 14, $95-106$.

[92] G. G. Podrebarac, F. T. T. Ng, G. L. Rempel, Chem. Eng. Sci., 1997, 52, $2991-3002$.

[93] L. Hong, E. Ruckenstein, Polymer, 1992, 33, 1968 - 1975.

[94] G.- J. Hwang, H. Ohya, J. Membr. Sci., 1998, 149, 163 - 169.

[95]G.- J. Hwang, H. Ohya, J. Membr. Sci., 1998, 140, 195 - 203.

[96] J. H. Hao, C. Chen, L. Li, L. Yu, W. Jiang, Desalination, 2000, 129, 15 - 22.

[97] PCT Patent: 01/61776, 2001, Forschungszentrum Jülich GmbH, Germany.

[98] US Patent Application: 2003/0049509, 2003.

[99] EP Patent: 1,256,142, 2001, Forschungszentrum Jülich GmbH, Germany.

[100] US Patent: 5,569,559, 1996, CNAM Paris and Electricitie de France, France.

[101] US Patent: 6,183,914, 2001, Reveo Inc., USA.

[102] PCT Patent: 00/16422, 2000, Reveo Inc., USA.

[103] EP Patent: 1,116,291, 2000, Reveo Inc., USA.

[104] PCT Patent: 02/35633, 2002, ABB AB and Volvo, Sweden.

[105] CN Patent: 1,402,370, 2003, University Wuhan, China.

[106] US Patent: 5,656,386, 1997, Paul Scherrer Institut, Switzerland.

[107] US Patent: 6,359,019, 2002, Ballard Power Systems Inc., Canada.

[108] PCT Patent: 01/58576, 2000, Ballard Power Systems Inc., Canada.

[109] S. J. Lee, S. Mukerjee, J. McBreen, Y. W. Who, Y. T. Kho, T. H. Lee, Electrochim. Acta, 1998, 24, 3693 - 3701. 
[110] S. E. Iyuke, A. B. Mohammas, A. A. H. Kadhum, W. R. W. Daud, C. Rachid, J. Power Sources, 2003, 114, $195-202$.

[111] S. C. Thomas, X. Ren, S. Gottesfeld, P. Zelenay, Electrochim. Acta, 2002, 47, 3741 3748.

[112] J. T. Mueller, P. M. Urban, J. Power Sources, 1998, 75, 139 - 143.

[113] J. T. Müller, P. M. Urban, W. F. Hölderich, J. Power Sources, 1999, 84, 157 - 160.

[114] J. Yu, B. Yi, D. Xing, F. Liu, Z. Shao, Y. Fu, H. Zhang, Phys. Chem. Chem. Phys., 2003, $5,611-615$.

[115] G. Hübner, E. Roduner, J. Mater. Chem., 1999, 9, 409 - 418.

[116] A. Panchenko, H. Dilger, E. Möller, T. Sixt, E. Roduner, J. Power Sources, 2004, 127, $325-330$.

[117] S. Dalihn, "Student wants vodka to power your cell phone", http://www.fuelcelltoday.com/FuelCellToday/IndustryInformation/IndustryInformationextern al/NewsDisplayArticle/0,1602,4212,00.html (30 ${ }^{\text {th }}$ March 2004), Fuel Cell Today Website, provided by St. Louis Post-Dispatch.

[118] A. S. Aricò, P. Cretì, P. L. Antonucci, V. Antonucci, Electrochem. Solid State Lett., 1998, $1,66-68$.

[119] W. Zhou, Z. Zhou, S. Song, W. Li, G. Sun, P. Tsiakaras, Q. Xin, Appl. Catal. B: Environ., 2003, 46, $273-285$.

[120] W. J. Zhou, B. Zhou, W. Z. Li, Z. H. Zhou, S. Q. Song, G. Q. Song, Q. Xin, S. Douvartzides, M. Goula, P. Tsiakaras, J. Power Sources, 2004, 126, 16 - 22.

[121] F. Vigier, C. Coutanceau, A. Perrard, E. M. Belgsir, C. Lamy, J. Appl. Electrochem., 2004, $34,439-446$.

[122] S. S. Gupta, S. S. Mahapatra, J. Datta, J. Power Sources, 2004, 131, 169 - 174x. 
[123] E. Peled, T. Duvdevani, A. Aharon, A. Melman, Electrochem. Solid State Lett., 2001, 4, A38 - A41.

[124] W. Hauffe, J. Heitbaum, Electrochim. Acta, 1978, 23, 299 - 303.

[125] R. B. de Lima, V. Paganin, T. Iwasita, W. Vielstich, Electrochim. Acta, 2003, 49, 85 91.

[126] M. Umeda, H. Sugii, M. Mohamedi, I. Uchida, Electrochemistry, 2002, 70, 961 - 963.

[127] Z. Qi, A. Kaufman, J. Power Sources, 2003, 118, 54 - 60.

[128] Z. Qi, A. Kaufman, J. Power Sources, 2002, 112, 121 -129.

[129] K. Yamada, K. Yasuda, N. Fujiwara, Z. Siroma, H. Tanaka, Y. Miyazaki, T. Kobayashi, Electrochem. Commun., 2003, 5, 892 - 896.

[130] S. C. Amendola, P. Onnerud, M. T. Kelly, P. J. Petillo, S. L. Sharp-Goldman, M. Binder, J. Power Sources, 1999, 84, 130 - 133. 
Table 1: The standard thermodynamic voltages $\left(E^{o}\right)$, energy densities $\left(W_{e}\right)$, and maximum reversible efficiencies $\left(\eta_{\text {rev }}\right.$ ) of hydrogen and selected pure alcohols when electrochemically oxidised $[9,10]$ under standard conditions. ${ }^{\dagger} 2$-propanol

Figure 1: A schematic of $(a)$ a proton-exchange membrane and $(b)$ an alkaline membrane fuel cell both fuelled either with $\mathrm{H}_{2}$ gas or directly with methanol. The stoichiometric ratio of reactants and products are shown in each case.

Figure 2: The graft penetration Raman-microscopy profile reproduced from reference [77], obtained with the radiation-grafting of vinylbenzyl chloride onto FEP fluoropolymer with a degree of grafting of $25.6 \%$ (ratio of mass gain / initial mass). The graph shows the variation in the ratio of intensities of the poly(vinylbenzyl chloride) band at $1002 \mathrm{~cm}^{-1}$ and the FEP band at $387 \mathrm{~cm}^{-1}$, which indicates the level of grafting at each point (spaced at $1 \mu \mathrm{m}$ ) throughout the thickness of the membrane.

Figure 3: The long-term ex situ thermal stability profile of a prototype RG-AAEM (of initial IEC $=0.71 \mathrm{meq}^{-1}$ ) produced by monitoring the IEC of membrane samples over time when heated in deionised water at temperatures of $60^{\circ} \mathrm{C}(\mathrm{O})$ and $100^{\circ} \mathrm{C}(\boldsymbol{\Delta})$; reproduced from reference [77]. The initial sharp drops in IEC are due to un-grafted residual quaternised poly(vinylbenzyl trimethylammonium hydroxide) formed as a by-product, which has leached out the during heat treatment in water.

Scheme 1: The generic structure of per-fluorinated polymers such as Nafion ${ }^{\circledR}$.

Scheme 2: The structure of polybenzimidazole (PBI) 
Scheme 3: The two alternative (and sometimes simultaneous) mechanisms of displacement of the trimethylammonium groups by hydroxide anions in AAEMs at elevated temperatures.

Scheme 4: The radiation-grafting of vinylbenzyl chloride onto FEP and subsequent amination and alkali-exchange, yielding alkaline anion-exchange membranes (RG-AAEMs).

Scheme 5: A thermally stable alkaline anion-exchange resin based on those reported by Tomoi et al. [81].

Scheme 6: Formation of AAEMs from polysulfone via a direct chloromethylation step.

Scheme 7: The benzyl $\mathrm{CH}_{\alpha}$ sites susceptible to peroxy-radical attack in poly(styrene sulfonic acid) (PSSA) and FEP-grafted poly(styrene sulfonic acid) (FEP-g-PSSA) at low pH. 


\begin{tabular}{cccc}
\hline Fuel & $\boldsymbol{E}^{\circ} / \boldsymbol{V}$ & $\boldsymbol{W}_{\boldsymbol{e}} / \mathbf{k W} \mathbf{~ h ~ k}^{\mathbf{- 1}}\left[\mathbf{k} \boldsymbol{W} \mathbf{h ~ d \boldsymbol { m } ^ { - 3 } ]}\right.$ & $\eta_{\boldsymbol{r e v}}$ \\
\hline Hydrogen $\left(\mathrm{H}_{2}\right)$ & 1.23 & $39.0\left[2.6\left(\right.\right.$ liquid $\left.\left.\mathrm{H}_{2}\right)\right]$ & 0.83 \\
Methanol $\left(\mathrm{CH}_{3} \mathrm{OH}\right)$ & 1.21 & $6.1[4.8]$ & 0.97 \\
Ethanol $\left(\mathrm{C}_{2} \mathrm{H}_{5} \mathrm{OH}\right)$ & 1.15 & $8.0[6.3]$ & 0.97 \\
Propanol $\left(\mathrm{C}_{3} \mathrm{H}_{7} \mathrm{OH}\right)$ & 1.07 & $8.6\left[6.8^{\dagger}\right]$ & 0.93 \\
Ethylene glycol $\left(\mathrm{HOC}_{2} \mathrm{H}_{4} \mathrm{OH}\right)$ & 1.22 & $5.3[5.9]$ & 0.99 \\
\hline
\end{tabular}

Table 1
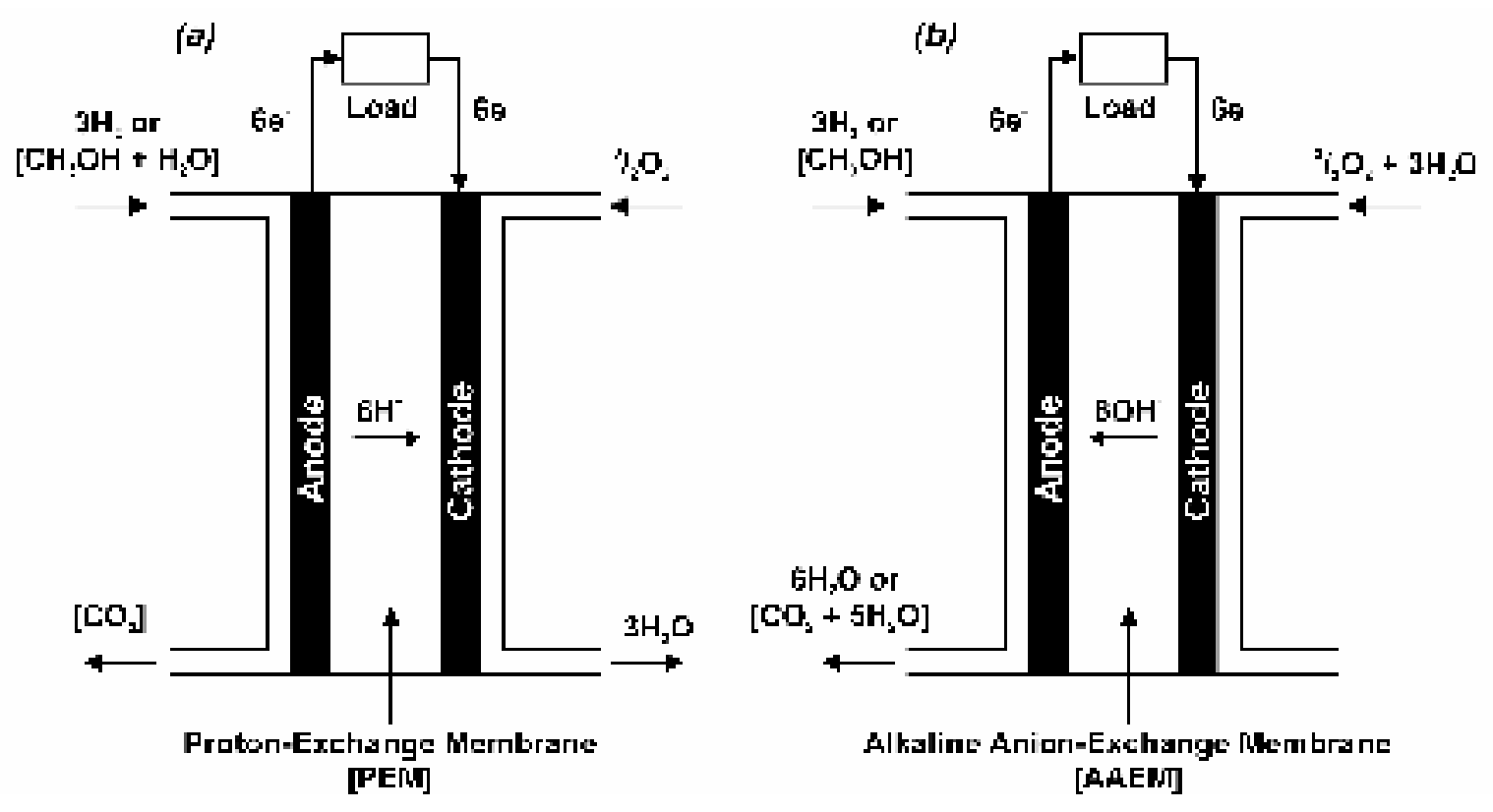

Figure 1 


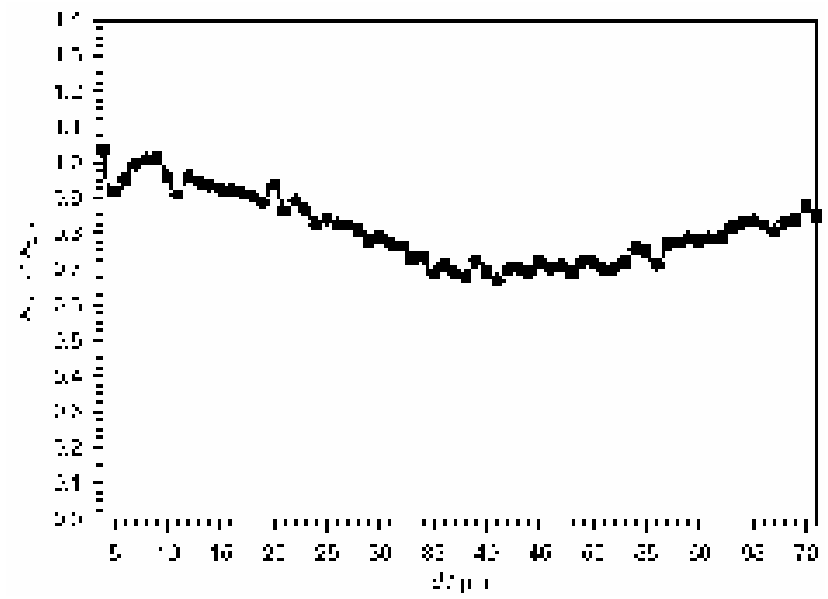

Figure 2

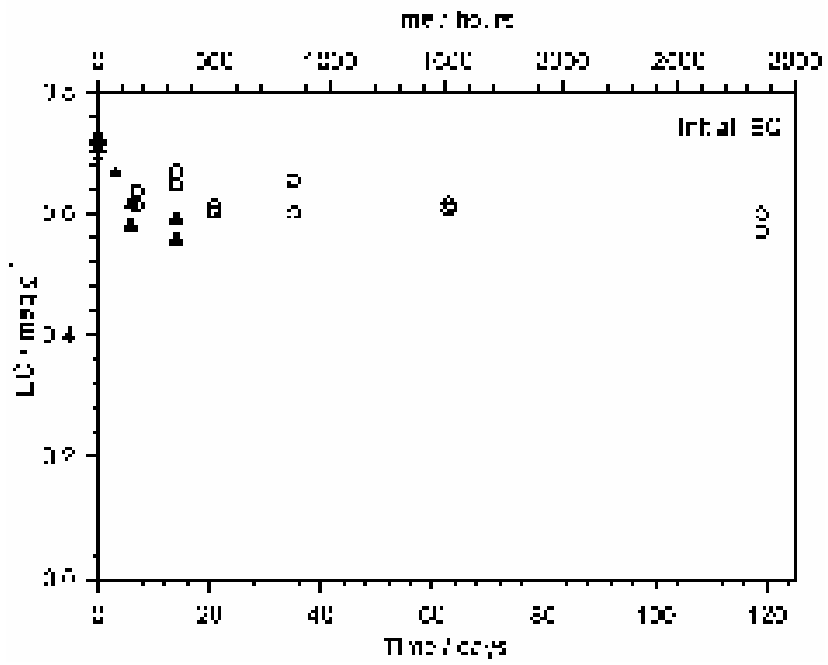

Figure 3

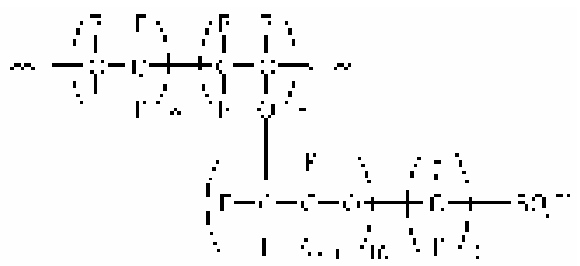

Scheme 1 


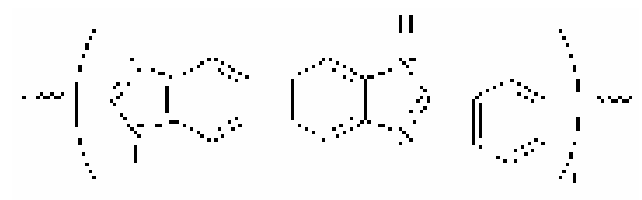

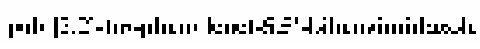

Scheme 2

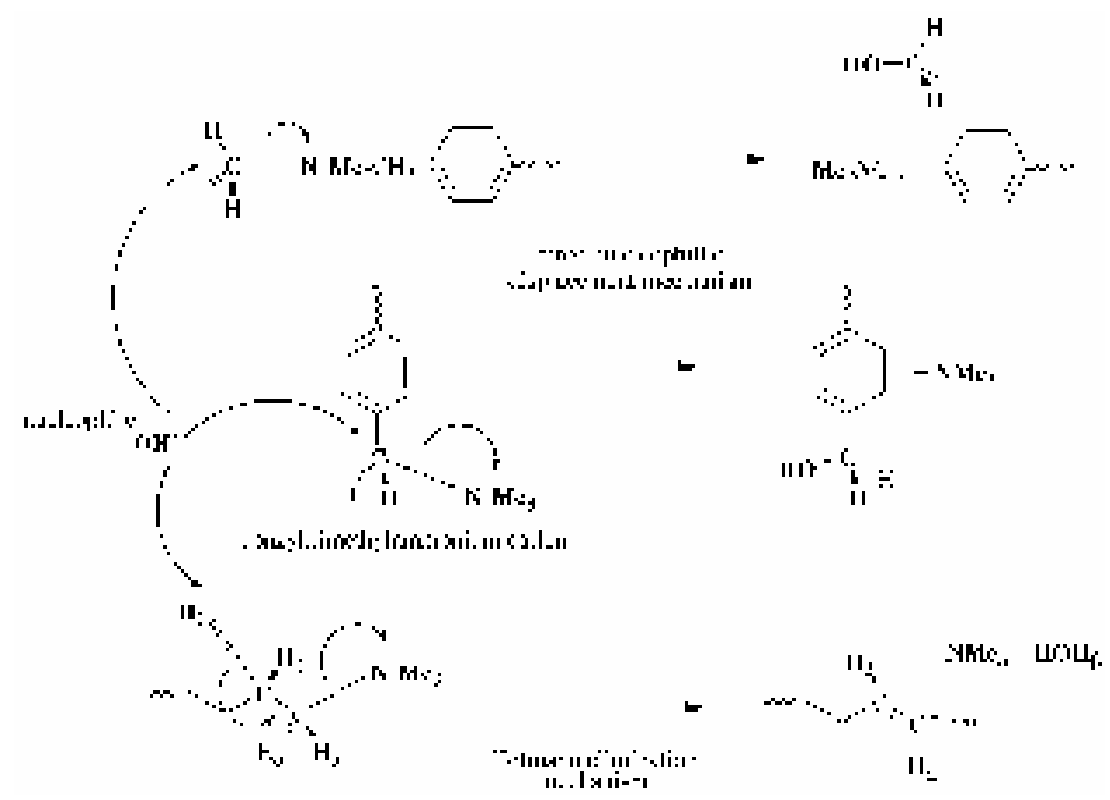

Scheme 3

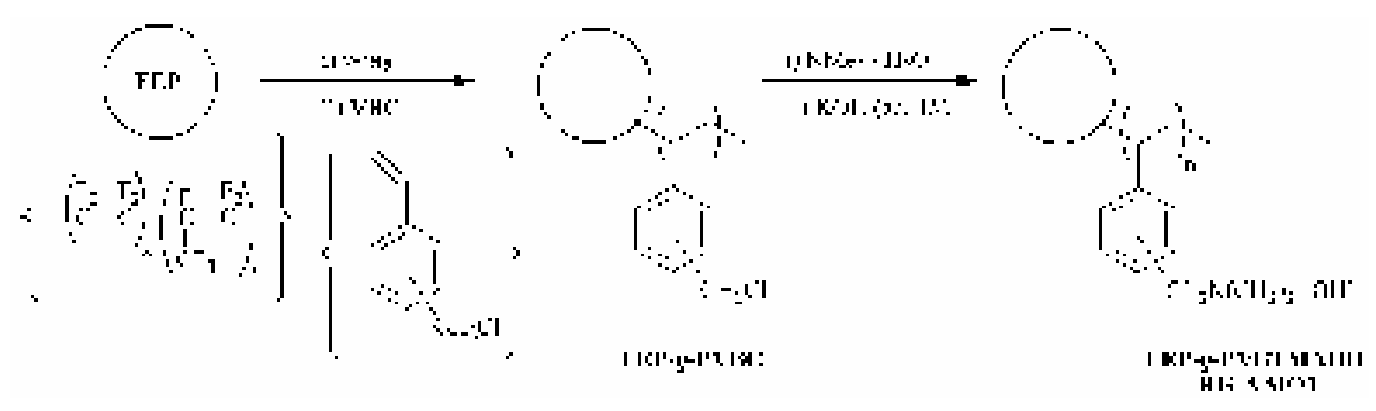

Scheme 4 


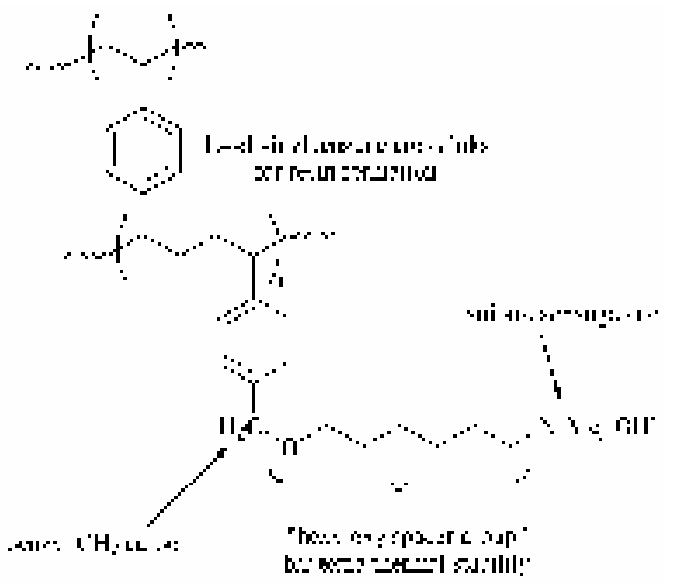

Scheme 5

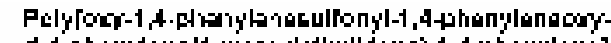

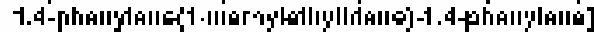

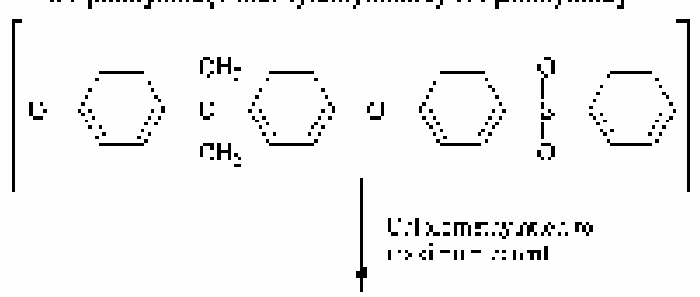

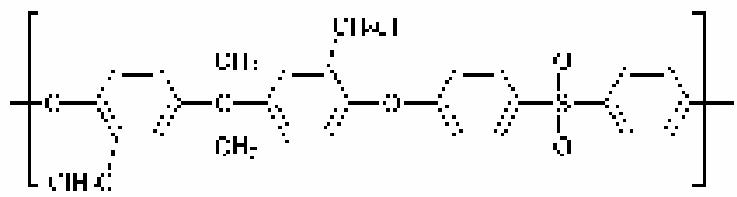

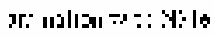

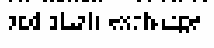

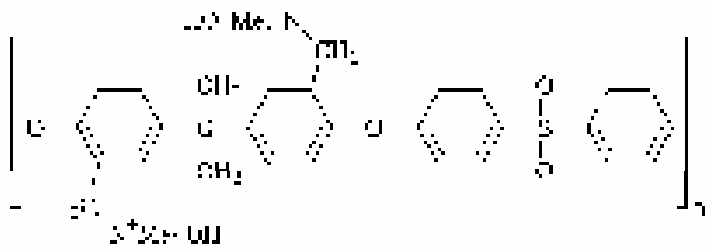

Scheme 6 


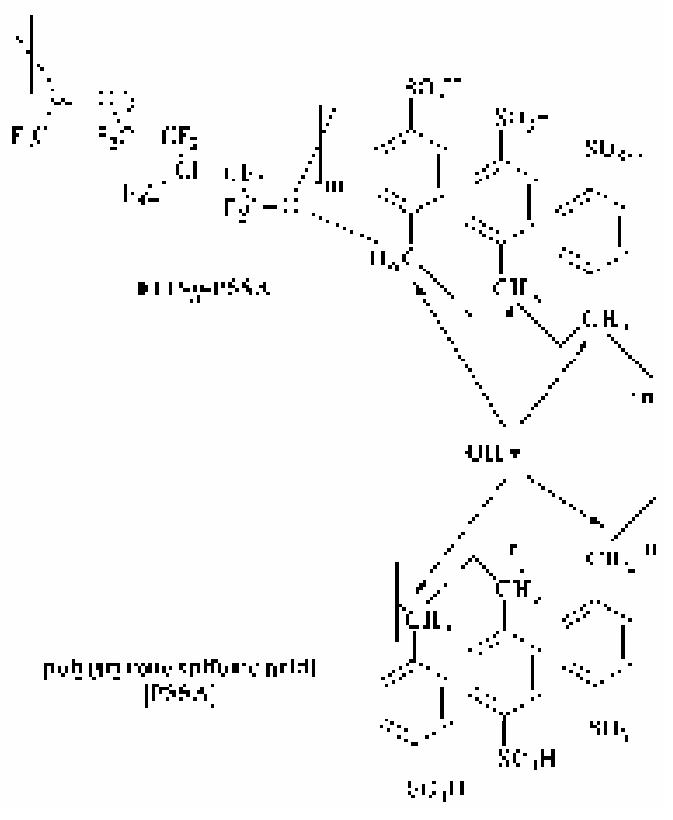

Scheme 7 